\title{
Influence of Various Wheat Genotypes and Agriculture Practices on Powdery Mildew Incidence
}

\author{
Ahmed Ameen Abdullah ${ }^{1 *}$, Tarek Youssef Bayoumi² and Waleed Ibrahim Shaban ${ }^{1}$ \\ ${ }^{1}$ Department of Agricultural Botany, Faculty of Agriculture, Suez Canal University, Ismailia, Egypt \\ ${ }^{2}$ Department of Agronomy, Faculty of Agriculture, Suez Canal University, Ismailia, Egypt
}

Received: $19 / 4 / 2015$

\begin{abstract}
A total of 61 wheat genotypes were screened for powdery mildew disease under natural infection during two seasons 2012/2013 and 2013/2014 in El Quantra Shark. Genotypes were sown in randomized complete block design in three replicates. The disease severity for all genotypes was measured to estimate the reaction of each genotype to infect with powdery mildew. The first scoring was done when the majority of genotypes were in the late booting stage. The second experiment to examine the effect of nitrogen fertilization and water deficiency on severity of powdery mildew disease and loss of yield. The experiment was carried out at the experimental Farm of Agronomy Department Fac., Agric., Suez Canal Univ., and Ismailia on Sids 12 wheat cultivar. Irrigation allocated at the main plots and the nitrogen fertilization allocated in sub main plots. Twelve lines showed moderately resistant reaction while thirty eight lines showed moderately susceptible and eleven lines recorded susceptible reaction to infect with Blumeria graminis tritici. The genotypes 2, 10, 11, Sakha 94, Sids 12, 66, 82, 89, 91 and 102 recorded the higher yields. Result indicates that increasing nitrogen dose from low $(50 \mathrm{~kg} / \mathrm{fad}$. $\mathrm{N})$ up to high $\mathrm{N}(100 \mathrm{~kg} / \mathrm{fad}$. $\mathrm{N})$ had a clear effect on powdery mildew infection.
\end{abstract}

\section{INTRODUCTION}

Wheat (Triticum aestivum L.) has been considered the main cereal grain grown in Egypt for thousands of years, serving as the principal source of calories in Egyptian diet. The five countries of North Africa (Algeria, Egypt, Libya, Morocco and Tunisia), are heavy users of wheat with a regional average consumption of $215.8 \mathrm{~kg} /$ caput (Curtis et al., 2002). During the period of 2000 to 2013 the average production in Egyptian wheat 8.01 million tons .However, the maximum production in season 2013, reached 9.5 million ton (Anonymous, 2014). Plant breeding and improvement of cultural practices were largely responsible for this achievement. Yield stability has increased substantially across environments due to the breeding of management-responsive, high-yielding, disease resistant, semi dwarf wheat cultivars, improved agronomic practices and the use of nitrogen fertilizers and irrigation treatments (Reynolds and Borlaug, 2006). Selection and breeding of plants with genetic resistance to parasites is one of the most effective methods of disease control.Surveys of select resistance sources can be used in wheat breeding programs (Niewoehner and Leath, 1998; Deb et al., 2002; Ahlawat, 2007). The amount of water available for crops is defined by the balance between precipitation and evapotranspiration. Wheat cultivation under periods of water deficit can significantly decrease yields (Emam et al., 2010; Roberto et al., 2012). There are very few reports studying the effect of irrigation on disease levels, although drought to increase the adult plant resistance to powdery mildew, which transmitted by rain splash, it might be affected by nitrogen supply and irrigation strategy (Olesen et al., 2003; Epstein and Bloom, 2005). Irrigation contributed to the emergence of leaf diseases. The lowest infection rates were observed in the treatments with no irrigation, water provided more favorable humid microclimate in stands, resulting more severe infection rates (Riera et al., 2005; Shao et al.,
2006; Maria, 2009). The objectives of this investigation aimed to compare disease severity of powdery mildew and their progress on bread wheat genotypes and recognize the effect of nitrogen fertilization on severity of powdery mildew disease in wheat.

\section{MATERIALS AND METHODS}

\section{1- Screening of wheat genotypes against powdery mildew disease.}

Wheat lines resulting from diallel program were exposed to, select intensity for productivity until F5 which were grown in El Quantra Shark, the east side of Suez Canal, Ismailia Governorate. After that, these lines were screened for powdery mildew disease. The material for this experiment includes 61 wheat genotypes to identify source or sources of résistance. These lines were sown in two seasons 2012/2013 and 2013/2014 in El Quantra Shark. The Experiment was consisting of 59 lines and two commercial wheat varieties (Sakha 94 and Sids 12). Lines were sown in randomized complete block design in three replicates, size plot $3.7 \times 2.75 \mathrm{~m}^{2}$ in averages, each plot consisted of 6 rows, $3 \mathrm{~m}$ long and $5 \mathrm{~cm}$ apart. The data for all lines and varieties were measured to estimate the reactions of disease severity in each line and variety to infect with powdery mildew the first scoring was done when themajority of lines were in the late booting stage. The susceptibility and resistance reactions of the screened wheat lines were assessed using a 0-5 scale (Khare and Lakpale, 1997), based on the progression of symptoms along the stem axis Table (1).

Reactions of these lines and varieties were tested under natural infection with powdery mildew Blumeria graminis tritici (DC.) Speer. No fungicides were sprayed to keep the crop under maximum disease severity conditions. The disease severity were taken weekly and recorded as mentioned before. When the plants reached the full maturity stage, spikes of all plots in the experiment were hand harvested and yield 
components were calculated including one thousand kernel weight $(\mathrm{g})$ and total weight of grain $(\mathrm{kg})$ per plot. Selected thousand grains from randomly each line were counted and weighted with an electronic balance to calculate 1000-kernel weight. Also, the weighted grains of the threshed spikes were measured with an electronic balance to calculate grain yield per plot for each line. In order to maintain crop vigor normal agronomic practices including recommended fertilization dose and irrigation schedule were applied. Diversity among these genotypes was estimated and grouping was made on the basis of cluster analysis.

Table (1): The evaluation scale of powdery mildew caused by Blumeria graminis tritici infection for wheat plant according to Khare and Lakpale (1997).

\begin{tabular}{ccc}
\hline Grade & Reaction & Leaf area covered in percent \\
\hline $\mathbf{0}$ & Immune (I) & No disease \\
$\mathbf{1}$ & Highly resistant (HR) & Up to 1 \\
$\mathbf{2}$ & Resistant (R) & 1 to 10 \\
$\mathbf{3}$ & Moderately Resistant (MR) & 10 to 25 \\
$\mathbf{4}$ & Moderately Susceptible (MS) & 25 to 50 \\
$\mathbf{5}$ & Highly Susceptible (HS) & $>50$ \\
\hline
\end{tabular}

\section{2- Influence of some agronomic practices on diseases severity of powdery mildew disease on wheat:}

Experiment was carried out at the experimental Farm of Agronomy Department Fac., Agric., Suez Canal Univ., Ismailia, Egypt during two successive seasons starting in 2012/2013 and 2013/2014 on wheat cultivar Sids 12. To examine the effect of nitrogen fertilization and water deficiency on severity of powdery mildew disease and loss of yield, The field trials comprised two factors (nitrogen $(\mathrm{N})$ and water deficit $(\mathrm{W})$ treatments) using three levels for Nitrogen and two for $\mathrm{W}$ in a split plot design, where, irrigation allocated the main plots and nitrogen fertilization allocated sub main plots. In the two water regimes, irrigation was withheld at tillering and flowering stages. The nitrogen levels were 50, 75 and $100 \mathrm{~N}$ unit/Feddan. Used Ammonium Nitrate which applied to wheat plants. The experimental plot consisted of 6 rows, $3 \mathrm{~m}$ long and $5 \mathrm{~cm}$ apart in which grains were drilled by hand. Wheat cultivar Sids 12 was grown in twenty seven plots $3 \times 3.5$ with $30 \mathrm{~cm}$ between rows. All plots were subjected to natural infection with powdery mildew, without using fungicide. Disease assessment scores for each plot were recorded weekly. Diseases were assessed on samples of leaves per plot selected at random throughout each plot. Disease severity was visually estimated by scored using 0 to 9 scales Xueren et al. (2012). The disease severity (DS) was also calculated by putting the collected data from the field into following formula:

D.S. $=\frac{\sum(0 \times \mathrm{N} 0+1 \times \mathrm{N} 1+2 \times \mathrm{N} 2+\ldots \ldots \ldots+9 \times \mathrm{N} 9)}{9 \times(\mathrm{N} 0+\mathrm{N} 1 \ldots \ldots \ldots \ldots \ldots+\mathrm{N} 9} \times 100$

Where: $n 0, n 1, n 2, n 3, n 4, n 5, n 6, n 7, n 8, n 9$ are the number of leaves with severity as $0,1,2,3,4,5,6,7,8$ and 9

The scale suggested in the formula for powdery mildew according to Mayee and Datar (1986)

$0=$ no symptoms.

$1=$ lesion covered on 1 to $10 \%$ of wheat leaves.
$2=$ lesion covered more than 10 to $20 \%$ of wheat leaves.

$3=$ lesion covered more than 20 to $30 \%$ of wheat leaves.

$4=$ lesion covered more than 30 to $40 \%$ of wheat leaves.

$5=$ lesion covered more than 40 to $50 \%$ of wheat leaves.

$6=$ lesion covered more than 50 to $60 \%$ of wheat leaves.

$7=$ lesion covered more than 60 to $70 \%$ of wheat leaves.

$8=$ lesion covered more than 70 to $80 \%$ of wheat leaves.

$9=$ lesion covered more than 80 to $100 \%$ of wheat leaves

\section{RESULTS AND DISCUSSION}

\section{1- Reaction of some wheat genotypes to infect with powdery mildew disease:}

Breeding for disease resistance is the most economically and environmentally safe method to reduce crop losses.Using the resistant cultivars one of the best ways for growing wheat to reduce the fungicides chemical for controlling diseases. The selected 61 wheat genotypes were screened against Blumeria graminis tritici (DC) Speer in the field under natural infection conditions during 2012/2013 and 2013/ 2014 seasons. The reactions of various lines are presented in Table (2) and (Figs. 1 and 2). In the first season 2012/2013, the disease severity differed among the tested wheat genotypes. The results show that 8 lines recorded DS\% between $1 \%$ to $10 \%$ while the 25 lines recorded DS $\%$ more than $10 \%$ to $20 \%$, while 20 lines + Sids $12+$ Sakha 94 recorded DS more than $20 \%$ to $30 \%$. Moreover 6 lines susceptible than others and recorded DS $\%>30$. In the second season 2013-2014, data in Table (2) and Fig.(1) also show that 8 lines recorded DS $1 \%$ to $10 \%$, while 27 lines were recorded DS more than $10 \%$ to $20 \%$ while 18 lines + Sids $12+$ Sakha 94 were recorded DS more than $20 \%$ to $30 \%$. While 6 lines were recorded more than DS $>30$. This result showed that wheat genotypes were affected differently from year to year. Yield losses varied according to the genotypes. Most of these differences were related to the various temperature and humidity conditions which recorded among the two years. Table (2) show that during 
seasons 2012/2013 and 2013/2014 the genotypes 2, 10, 11, Sakha 94, Sids 12, 66, 82, 89, 91 and 102 revealed the highest yield response from the yield analysis. Evidence of differences in tolerance, measured as response of yield to disease-induced changes in powdery mildew, was found across a comparison of cultivated. These differences were large enough to be of agronomic importance. On a limited subset of the data, there was no evidence that tolerance, quantified through measurement of powdery mildew, which differed within variety between experiments. This indicates that genotypic differences were responsible for the differences in tolerance. It is likely that some traits conferring tolerance have associated yield penalties. Equally, however, some may have positive or neutral effects on attainable yield. In this study there was evidence for tolerance being associated with lower yield potential. Bread wheat yield was affected by genotype and year. Changes in the proportion of susceptible and resistant genotypes and weather explained differences within and between years.

Powdery mildew had a major effect on yield loss and its attributes. Significant changes in many factors were observed over the period 2013-2014, e.g.in soil organic matter, soil $\mathrm{pH}$, sand and silt fraction, total nitrogen, day of sowing, Furthermore, literatures found significant correlations and interactions among many of these factors (Fernandez et al., 2010). Bailey et al. (2001) reported that crop rotation have a limited impact on wheat disease severity and the prevalence of fungal species relative to the environment. The use of genetic resistance in wheat is the most economical way of controlling the disease (Chen and line, 1992).

In general, there are two mechanisms of resistance to powdery mildew: seedling resistance, which can be expressed in all stages of plant development, and maturity resistance plant, which expresses in maturity stages. In this regard other investigators such as Bowen et al. (1991), Niewoehner and Leath (1998), Singh and Rajaram (2002), Samobor et al. (2005) and Ahlawat (2007) reported that control on any disease might be done along several lines. Resistant varieties offer the best means of controlling the disease. Chen (2005) suggested that the term seedling all-stage resistance and some types of maturity plant resistance are race specific (Chen and Line, 1992; Chen, 2005). Genotypes possessing only race specific resistance in most cases lose their resistance over time due to the occurrence of more virulent powdery mildew races. These races evolve due to high selection pressure on the pathogen, which is caused by growing resistant wheat cultivars on large numbers of acres (Line and Qayoum, 1992). Genotypes possessing only race specific resistance in most cases lose their resistance over time due to the occurrence of more virulent powdery mildew races. These races evolve due to high selection pressure on the pathogen, which is caused by growing resistant wheat cultivars on large numbers of acres (Line and Qayoum, 1992).

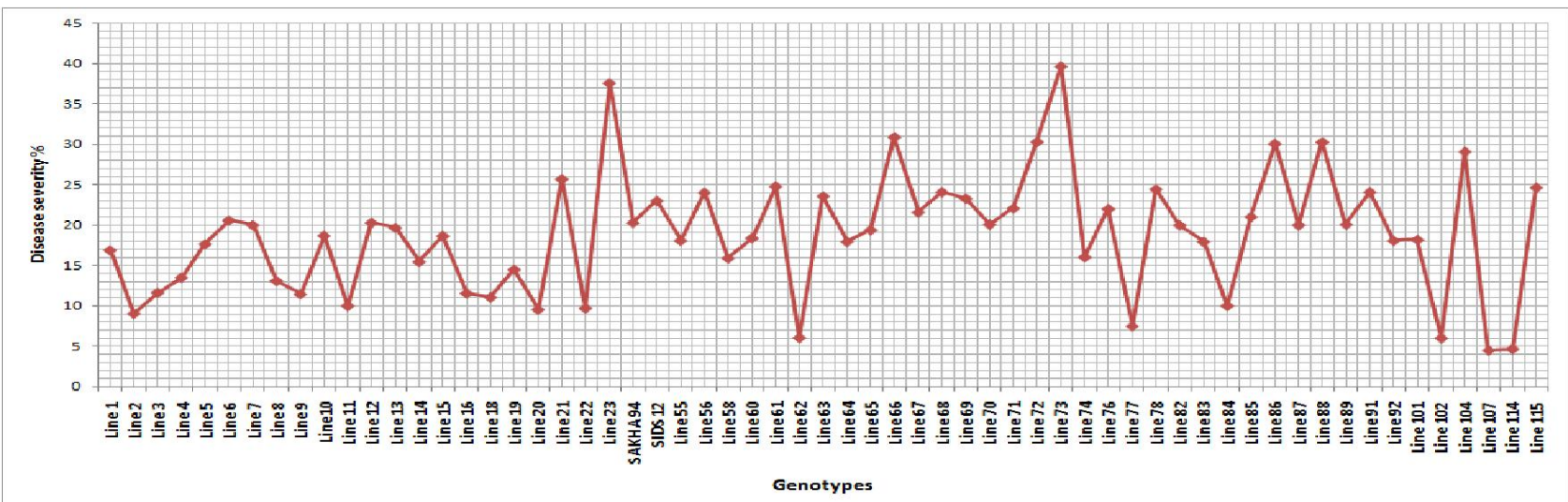

Fig. (1). Reactions of 61 wheat genotypes to powdery mildew during 2012-2013 season.

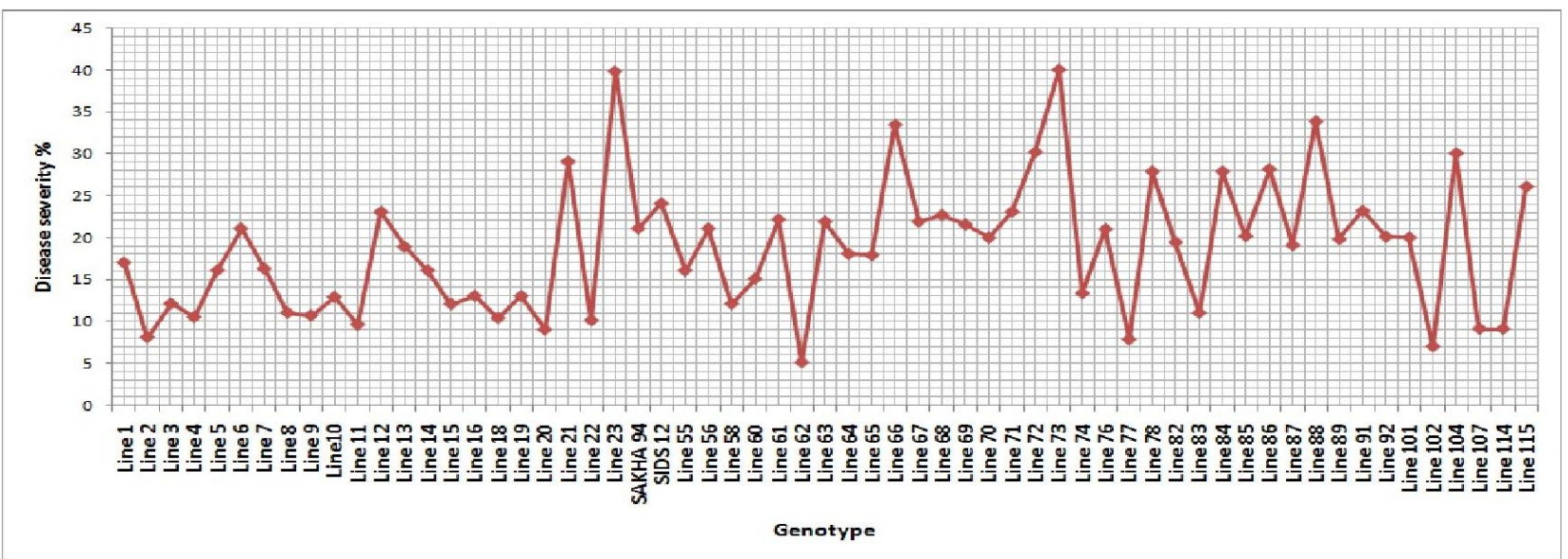

Fig. (2). Reactions of 61 wheat genotypes to powdery mildew during 2013-2014 season. 
Table (2): Effect of powdery mildew infection on yield and 1000 kernel weight (gm) of 61 wheat genotype during 2012/13 and 2013/14 growing seasons.

\begin{tabular}{|c|c|c|c|c|c|c|c|}
\hline \multirow[b]{2}{*}{ Lines } & \multicolumn{3}{|c|}{$2012 \backslash 2013$} & \multicolumn{3}{|c|}{$2013 \backslash 2014$} & \multirow[b]{2}{*}{ Reaction score* } \\
\hline & $\begin{array}{c}\text { Disease severity } \\
(\%)\end{array}$ & $\begin{array}{c}1000 \text { kernel } \\
\text { weight }(\mathrm{g})\end{array}$ & $\begin{array}{c}\text { Yield weight } \\
(\mathrm{kg}) / \mathrm{m}^{2}\end{array}$ & $\begin{array}{c}\text { Disease severity } \\
(\%)\end{array}$ & $\begin{array}{c}1000 \text { kernel } \\
\text { weight (g) }\end{array}$ & $\begin{array}{c}\text { Yield weight } \\
(\mathrm{kg}) / \mathrm{m}^{2}\end{array}$ & \\
\hline Line 1 & 16.90 & 42.90 & 02.25 & 17.03 & 43.30 & 00.55 & MR \\
\hline Line 2 & 09.06 & 30.70 & 03.30 & 08.10 & 52.70 & 01.90 & $\mathrm{R}$ \\
\hline Line 3 & 11.66 & 31.70 & 03.85 & 12.10 & 44.70 & 00.90 & MR \\
\hline Line 4 & 13.50 & 49.80 & 02.90 & 10.50 & 57.60 & 00.50 & MR \\
\hline Line 5 & 17.67 & 49.10 & 01.80 & 16.09 & 45.10 & 00.60 & MR \\
\hline Line 6 & 20.60 & 45.30 & 03.20 & 21.09 & 55.00 & 00.75 & MR \\
\hline Line 7 & 20.01 & 43.50 & 02.20 & 16.30 & 39.90 & 00.70 & MR \\
\hline Line 8 & 13.10 & 42.10 & 01.40 & 11.02 & 56.00 & 01.8 & MR \\
\hline Line 9 & 11.46 & 37.30 & 02.80 & 10.70 & 49.60 & 01.45 & MR \\
\hline Line10 & 18.70 & 47.60 & 02.80 & 12.90 & 56.60 & 01.80 & MR \\
\hline Line 11 & 10.01 & 47.30 & 03.80 & 09.61 & 53.80 & 02.10 & $\mathrm{R}$ \\
\hline Line 12 & 20.30 & 42.90 & 02.15 & 23.09 & 35.30 & 00.80 & MR \\
\hline Line 13 & 19.66 & 39.00 & 02.30 & 18.90 & 55.60 & 01.65 & MR \\
\hline Line 14 & 15.47 & 44.60 & 03.10 & 16.08 & 45.50 & 01.65 & MR \\
\hline Line 15 & 18.66 & 51.70 & 03.25 & 12.06 & 54.50 & 01.50 & MR \\
\hline Line 16 & 11.56 & 42.90 & 02.15 & 13.04 & 39.80 & 01.20 & MR \\
\hline Line 18 & 11.06 & 42.00 & 02.20 & 10.38 & 48.30 & 01.50 & MR \\
\hline Line 19 & 14.50 & 26.90 & 03.15 & 13.01 & 44.00 & 00.40 & MR \\
\hline Line 20 & 09.56 & 44.50 & 02.80 & 09.00 & 46.50 & 01.45 & $\mathrm{R}$ \\
\hline Line 21 & 25.70 & 51.90 & 01.55 & 29.09 & 42.90 & 01.25 & MS \\
\hline Line 22 & 09.72 & 45.50 & 03.90 & 10.09 & 46.40 & 00.80 & $\mathrm{R}$ \\
\hline Line 23 & 37.58 & 35.80 & 02.35 & 39.88 & 41.40 & 00.50 & MS \\
\hline SAKНА 94 & 20.30 & 34.50 & 02.30 & 21.09 & 31.10 & 01.90 & MR \\
\hline SIDS 12 & 23.01 & 42.60 & 02.25 & 24.09 & 40.20 & 02.00 & MR \\
\hline Line 55 & 18.10 & 51.70 & 03.15 & 16.07 & 41.30 & 00.50 & MR \\
\hline Line 56 & 24.03 & 40.10 & 03.45 & 21.09 & 42.80 & 01.85 & MR \\
\hline Line 58 & 15.90 & 36.60 & 04.50 & 12.09 & 51.20 & 00.95 & MR \\
\hline Line 60 & 18.40 & 45.10 & 04.05 & 15.09 & 53.80 & 01.00 & MR \\
\hline Line 61 & 24.80 & 41.30 & 03.40 & 22.18 & 48.50 & 00.70 & MR \\
\hline Line 62 & 6.06 & 47.90 & 03.40 & 05.08 & 60.00 & 01.10 & $\mathrm{R}$ \\
\hline Line 63 & 23.60 & 43.90 & 03.35 & 21.90 & 46.00 & 03.80 & MR \\
\hline Line 64 & 17.96 & 51.20 & 04.70 & 18.06 & 63.40 & 01.65 & MR \\
\hline Line 65 & 19.40 & 44.20 & 01.70 & 17.90 & 59.60 & 01.00 & MR \\
\hline Line 66 & 30.90 & 39.00 & 03.85 & 33.50 & 55.10 & 01.80 & MS \\
\hline Line 67 & 21.60 & 42.90 & 03.70 & 21.90 & 49.10 & 01.35 & MR \\
\hline Line 68 & 24.10 & 44.60 & 04.15 & 22.70 & 51.50 & 01.35 & MR \\
\hline Line 69 & 23.30 & 34.30 & 03.85 & 21.56 & 47.60 & 01.20 & MS \\
\hline Line 70 & 20.09 & 45.10 & 02.85 & 19.98 & 54.60 & 01.15 & MR \\
\hline Line 71 & 22.09 & 42.90 & 06.50 & 23.11 & 67.90 & 00.95 & MR \\
\hline Line 72 & 30.33 & 42.50 & 03.10 & 30.24 & 45.70 & 01.20 & MS \\
\hline Line 73 & 39.66 & 35.40 & 03.05 & 40.09 & 50.70 & 01.55 & MS \\
\hline Line 74 & 16.04 & 32.50 & 02.85 & 13.34 & 47.80 & 01.75 & MR \\
\hline Line 76 & 22.01 & 48.90 & 05.5 & 21.01 & 50.60 & 01.25 & MR \\
\hline Line 77 & 07.50 & 33.60 & 02.00 & 07.82 & 52.70 & 01.55 & $\mathrm{R}$ \\
\hline Line 78 & 24.46 & 36.10 & 02.65 & 27.90 & 52.20 & 00.95 & MS \\
\hline Line 82 & 20.00 & 36.00 & 02.70 & 19.45 & 53.80 & 02.00 & MR \\
\hline Line 83 & 17.96 & 18.99 & 2.55 & 11 & 43.9 & 1.65 & MR \\
\hline Line 84 & 10.01 & 39.5 & 5.5 & 27.9 & 51.8 & 1.15 & MS \\
\hline Line 85 & 21.04 & 32.5 & 3.05 & 20.19 & 50.1 & 1.35 & MR \\
\hline Line 86 & 30.08 & 42 & 2.85 & 28.19 & 43 & 1.05 & MS \\
\hline Line 87 & 20.01 & 15.97 & 4.2 & 19.1 & 35.6 & 1.15 & MR \\
\hline Line 88 & 30.3 & 29.8 & 2.9 & 33.9 & 35.3 & 1.7 & MS \\
\hline Line 89 & 20.09 & 40 & 2.85 & 19.81 & 58.8 & 2 & MR \\
\hline Line 91 & 24.1 & 57.7 & 2.2 & 23.2 & 50.8 & 2.65 & MR \\
\hline Line 92 & 18.09 & 19.9 & 3 & 20.09 & 42.2 & 1.3 & MR \\
\hline Line 101 & 18.2 & 47.2 & 1.6 & 20 & 48.3 & 1.3 & MS \\
\hline Line 102 & 6.01 & 57.2 & 3 & 6.99 & 39.2 & 2.65 & MR \\
\hline Line 104 & 29.1 & 44.9 & 3.2 & 30.09 & 51.1 & 1.1 & MS \\
\hline Line 107 & 4.5 & 50 & 2 & 9.1 & 47.3 & 1.4 & $\mathrm{R}$ \\
\hline Line 114 & 4.66 & 33.1 & 2.85 & 9.1 & 37.2 & 0.65 & $\mathrm{R}$ \\
\hline Line 115 & 24.66 & 34 & 2.38 & 26.1 & $\varepsilon V . V$ & 1.35 & MS \\
\hline
\end{tabular}

* MR: Moderately Resistant reaction

MS: Moderately susceptible reaction

S: Susceptible reaction 
Although certain types of maturity plant resistances are sometimes race- specific, high temperature maturityplant resistance (HTAP), also known as 'temperature sensitive resistance' (Roelfs et al., 1992) is race- nonspecific and is one of the most effective types of maturity plant resistance, which is triggered in the late stages of plant development when temperature increases. Therefore, an attempt was made to identify sources of resistance which can be used in developing resistant cultivars or directly used as such with a view to mitigate loss in farmers' fields.

\section{1- Effect of some agriculture practices on wheat diseases severity of powdery mildew.}

Wheat cultivar Sids 12 was subjected to two water regimes and three nitrogen levels to explore the effect of nitrogen and water status on disease dispersal and losses of yield. Data indicate data in Table (3) that increasing nitrogen dose from low $\mathrm{N}(50 \mathrm{~kg} /$ Feddan.) up to high $\mathrm{N}$ $(100 \mathrm{~kg} / \mathrm{Fe} . \mathrm{N})$ had an accelerating significant effect on infection of powdery mildew. Moreover, with holding irrigation at flowering stage was more serious on powdery mildew disease severity than tillering stage. Damage was mostly severe with water stress and became more dangerous when heavy infection occurs during periods of rapid growth, tillering, stem elongation and head development. Powdery mildew is associated with dense plant growth cool and moist conditions. Powdery mildew is most severe on wheat grown in soils with high nitrogen content (Emam et al., 2010). The dense growth which resulted from excessive nitrogen fertilizer will from creates ideal environmental conditions for disease development (Olesen et al., 2003). Nitrogen application commonly increases leaf Nitrogen concentration, with contrasting effects on disease severity (Simón et al., 2003).

Disease severity increased from $19.18 \%$ up to $38.7 \%$ with increasing nitrogen level from 50 to $100 \mathrm{Kg} \mathrm{N} / \mathrm{Fe}$ at tillering stage of water stress. While, damage was more severe $(40.24 \%)$ when water stress was applied at flowering stage and accompanied with high $\mathrm{N}$ level in season 2012/2013. N-deficiency (50Kg N/Fadden). These symptoms became more pronounced during the water stress. Yield response to $\mathrm{N}$ application rate has been studied in this experiment. Yield increased resulting from $50 \mathrm{~N}$ rates $(1378.22 \mathrm{Kg} / \mathrm{Fe}$.) to $(1714.4$ $\mathrm{Kg} / \mathrm{Fe}$.) with $100 \mathrm{~N}$ rates at tillering stage. While, yield varied from $1124.96 \mathrm{Kg} / \mathrm{Fe}$ at $50 \mathrm{~N}$ rate to $1457 \mathrm{Kg} / \mathrm{Fe}$ at $100 \mathrm{~N}$ rate in the flowering stage. The same results were observed in the second season 2013/2014 Table (4).

Table(3): Effect of water deficit and nitrogen levels on disease severity of powdery mildew for wheat (variety Sids 12) 2012-2013season.

\begin{tabular}{lcccccc}
\hline $\begin{array}{c}\text { Withholding } \\
\text { irrigation }\end{array}$ & \multicolumn{3}{c}{ Tillering stage } & \multicolumn{3}{c}{ Flowering stage } \\
\hline N rate kg/Fe & 50 & 75 & 100 & 50 & 75 & 100 \\
DS\% & 19.18 & 26.08 & 38.37 & 17.80 & 27.10 & 40.24 \\
Yield Kg/Fe & 1378.22 & 1519.20 & 1714.40 & 1124.1906 & 1264.40 & 1457.00 \\
\hline
\end{tabular}

Feddan $=4200 \mathrm{~m}^{2}$

Table (4): Effect of water deficit and nitrogen levels on disease severity of powdery mildew for wheat (variety Sids 12) 2013-2014 season.

\begin{tabular}{lllllll}
\multicolumn{1}{c}{$\begin{array}{c}\text { Withholding } \\
\text { irrigation }\end{array}$} & \multicolumn{2}{c}{ Tillering stage } & \multicolumn{2}{c}{ Flowering stage } \\
\hline N rate kg/Fadden & 50 & 75 & 100 & 50 & 75 & 100 \\
DS\% & 14.00 & 15.45 & 25.45 & 18.00 & 22.90 & 31.94 \\
Yield Kg/Fadden & 1342.00 & 1493.50 & 1866.00 & 1325.00 & 1496.00 & 1503.00 \\
\hline
\end{tabular}

Yield reduction was more pronounced in the second season than the first one. This might be due to the interaction effect among factor and weather factors as well as water stress. Where, plants were subjected to several environmental stresses which adversely affect growth, metabolism and yield. There was a relationship between disease severity and rate of nitrogen as well as plant water status which raises the possibility of an unexpected mechanism, and implies that its primary effect might have been on infection, rather than fungal growth. Generally, changing management practices might affect the level of disease infection, as well as crop susceptibility to disease. The relationship between $\mathrm{N}$ rates and disease severity had severalfacts. It is clear that the dense canopy, increasing $\mathrm{N}$ rates will result, slows themovement of air in the crop, and can result in higher relative humidity and prolong the leaf wetness (Tompkins et al., 1993). This gives more suitable environment for condition the growth of some pathogens (Olesen et al., 2003). However, (Cox et al., 2004) found that increasing $N$ led to increase susceptibility to powdery mildew in barley even aside from the canopy effect. It is also clear that plants were inherently more susceptible to powdery mildew where 
high $\mathrm{N}$ rates were applied, even when spaced out to mitigate the canopy density effect. Olesen et al. (2003) found that resistant variety to powdery mildew had little increase in disease incidence under higher $\mathrm{N}$ rates, while a susceptible variety had a dramatically higher incidence. They also note that disease progress is complex and depends on multiple factors, of which $\mathrm{N}$ fertility is one. Other researchers have also noted an increase in powdery mildew severity with increase $\mathrm{N}$ application rate (Simón et al., 2003). They also concluded that increase $\mathrm{N}$ fertilization leads to more severe powdery mildew infestations under conditions conducive to the growth of casual organism of the disease. Nitrogen nutrition is thought to be an important environmental factor affecting quantitative resistance to the disease. It is also clear that high $\mathrm{N}$ fertilization is associated with increase severities of some foliar diseases such as cereal rusts and mildew.

\section{REFERENCES}

Ahlawat, M. (2007). Crop Diseases and their management. Available online htpp://www.fao.org.

Anonymous, (2014). Statistical databases. Food and Agriculture Organization of the United Nations.

Bailey, K.L., B.D. Gossen, R.K. Gugel, and R.A.A. Morrall (2001). Diseases of Field Crops in Canada. Canadian Phytopathological Society, Saskatoon J, pp 97-106.

Bowen, K., K. Everts and S. Leath (1991). Reduction in yield of winter wheat in North Carolina due to powdery mildew and leaf rust. Phytopathology, 81: 503-511.

Chen, X.M. (2005). Epidemiology and control of stripe rust (Puccinia striiformis. f $\mathrm{sp}$. tritici) on wheat Canadian Journal of Plant Pathology, 27: 120125.

Chen, X.M. and R. F. Line (1992). Inheritance of stripe rust resistance genes in wheat cultivars used to differentiate North American races of Puccinia striiformis. Phytopathology, 82: 1428-1434.

Cox, C.M., K.A. Garrett, R.L. Bowden, A.K. Fritz, S.P. Dendy and W.F. Heer (2004). Cultivar mixtures for the simultaneous management of multiple disease: Tan spot and leaf rust of wheat. Phytopathology, 94: 961-969.

Curtis, B.C., S. Rajaram and H. G. Macpherson (2002). Bread wheat improvement production, FAO plant production and protection series NO.30 Available at http://www.fao.org/

Emam, Y, A. Shekoofa, F. Salehi and A.H. Jalali (2010). Water stress effects on two common bean cultivars with contrasting growth habits. American-Eurasian Journal of agriculture and environmental science, 9 (5): 495-499.

Epstein, E. and A.J. Bloom (2005). Mineral nutrition of plants: Principles and Perspectives. Sunderland, Massachusetts: Sinauer Associates, Inc., 400 pp.

Fernandez, R., A. Quiroga, C. Zoratti and E. Noellemeyer (2010). Carbon contents and respiration rates of aggregate size fractions under no-till and conventional tillage. Soil and Tillage Research, 109: 103-109.
Khare, N. and N. Lakpale (1997). Sources of resistance to powdery mildew. Journal of Mycology and Plant Pathology, 27: 219-220.

Line, R.F. and A. Qayoum (1992).Virulence, aggressiveness, evolution, and distribution of races of Puccinia striiformis (the cause of stripe rust of wheat) in North America, 1968-87. US Department of Agriculture, Agricultural Research Service Technical Bulletin, 1788.

Maria, H. (2009). Study of the effect of major agro technical factors in winter wheat production. Ph.D. Thesis, University of Debrecen, Hungary, p. 23.

Niewoehner, A.S. and S. Leath (1998). Virulence of Blumeria graminis f. sp. tritici on winter wheat eastern United States. Plant Disease, 82: 64-68.

Olesen, J.E., L.N. Jorgensen, J. Petersen and J.V. Mortensen (2003). Effects of rate and timing of nitrogen fertilizer on disease control by fungicides in winter wheat grain yield and foliar disease control. Journal of Agricultural Science, 140: 1529.

Deb, K., A. Pratap, S. Agarwal and T. Meyarivan (2002). A fast and elisit Mutliobjective genetic algorithm: Transatinon, Evolutionar Computation, 6: 182-197.

Reynolds, M.P. and N.E. Borlaug (2006). Impacts of breeding on international collaborative wheat improvement. Journal of Agricultural Science, 144: 3-17.

Riera, M., C. Valon, F. Fenzi, J. Giraudat and J. Leung (2005). The genetics of adaptive responses to drought stress: abscisic acid-dependent and abscisic acid-independent signaling components. Physiol Plantarum, 123: 111-119.

Roberto P. Marano, Roxana L. Maumary, Laura N. Fernandez and Luis M. Rista (2012). Epidemiology of the diseases of wheat under different strategies of supplementary irrigation. International Journal of Agronomy, 110, Article I D 407365, pp. 11.

Roelfs, A.P., R.P. Singh and E.E. Saari (1992). Rust diseases of wheat: Concepts and methods of diseases management. Mexico, D.F. CIMMYT., 81. p. 55 .

Samobor, V., M. Vukobratović and M. Jošt (2005). Effect of powdery mildew (Erysiphe graminis D.C. f. sp. tritici) attack on yield and physical parameters of wheat (Triticum aestivum spp vulgare) grain quality. Agriculture, 11(2): 30-37.

Shao, H.B., X.Y. Chen, L.Y. Chu, X.N. Zhao, G. Wu, Y.B. Yuan, C.X. Zhao and Z.M. Hu (2006). Investigation on the relationship of proline with wheat anti-drought under soil water deficits, Colloids Surf. B: Biointerfaces, 53: 113-119.

Simón, M.R., C.A. Cordo, A.E. Perello and P.C. Struik (2003). Influence of nitrogen supply on susceptibility of wheat to Septoria tritici. Journal of Phytopathology, 151: 283-289.

Singh, R.P. and S. Rajaram (2002). Breeding for disease resistance in wheat, FAO Plant Production and Protection Series, No. 30. 
Tompkins, D.K., D.B. Fowler and A.T. Wright (1993). Influence of agronomic practices on canopy microclimate and septoria development in no-till winter wheat produced in the Parkland region of Saskatchewan. Canadian Journal of Plant Science, 73: 331-344.
Xueren, C., D. Xiayu, Z. Yilin and L. U. Yong (2012). Dynamics in concentrations of Blumeria graminis f. sp tritici conidia and its relationship to local weather conditions and disease index in wheat. European journal of plant pathology, 132: 525535.

\section{تأثير مجموعة من التراكيب الوراثية وبعض المعاملات الزراعية على ظهور مرض البياض الاقيقي على نباتات القمع \\ احمد أمين عبد اللها ـ طارق يوسف بيومي²ـ وليد إبراهيم شعبان1

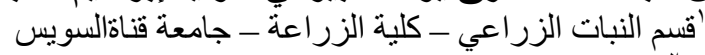

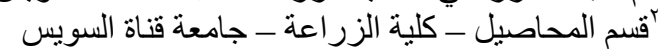

تم إجر اء هذه الدر اسة في تجربتين، كانت التجربة الأولى بفحص إب سلالة قمح لقياس رد فعلها تجاه الاصابة بمرش البياض الدقيقى تحت

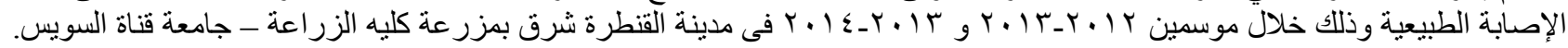

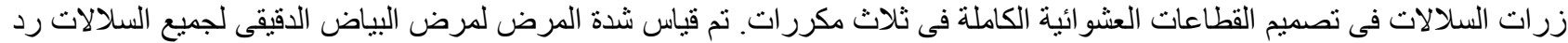

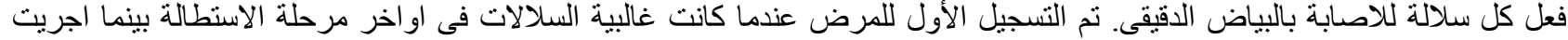

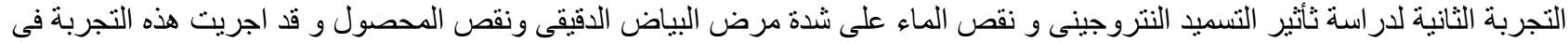

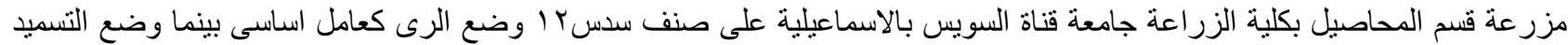

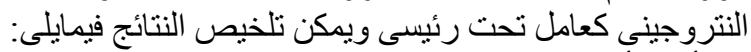

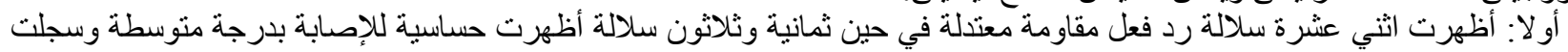

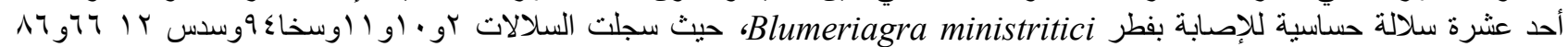

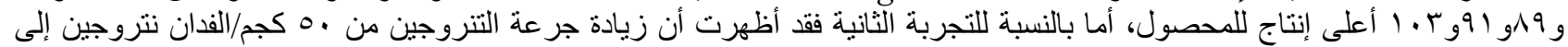
• . . اكجم /الفدان نتروجين كان لها تأثير على زيادة الإصابة بمرض البئ البياض الدقيقى في القمح. 